Revista de Journal of Integrated
GESTÃO COSTELRA Integrada COSTALZONE MANAGEMENT

\title{
Anthropogenic influence on the sedimentary dynamics of a sand spit bar, Patos Lagoon Estuary, RS, Brazil *
}

\author{
Paulo Victor Lisboa ${ }^{\circledR}$, a; Elisa Helena Fernandes ${ }^{\text {a }}$
}

\begin{abstract}
Known to be transition zones between the sea and the mainland, estuaries are recognized for their socio-economic and ecological importance as well as their complexity and vulnerability to anthropogenic influences, harbor activities included. It is reasonable to consider that these influences produce changes in the dynamics of the region, resulting in modifications related to the biota, sediment transport, and flows between the estuary and the adjacent coastal zone. The possible changes in the sediment budget of the Patos Lagoon estuary can affect fragile features present in the estuary such as sand spits. The objective of this work is to evaluate the effect of the modernization work carried out at Rio Grande Harbor access channel on a specific sand spit called Pontal Sul as an indicator of the sediment dynamics alteration in the Patos Lagoon estuary. The study is based on numerical modeling experiments with the TELEMAC-3D model and remote sensing techniques (Quickbird images). Results indicate that the Rio Grande Harbor modernization work changed the Pontal Sul erosion and deposition rates and longitudinal growth. The results suggest that the modification carried out at Rio Grande Harbor access channel changed the Patos Lagoon sediment dynamics.
\end{abstract}

Key Words: Anthropic influence, erosion, deposition, harbors, numerical modeling.

\section{Resumo}

\section{Influência antropogênica sobre a dinâmica sedimentar de um pontal, estuário da Lagoa dos Patos, RS, Brasil}

Conhecidos por serem zonas de transição entre o mar e o continente, os estuários são ambientes referidos pela sua importância sócio-econômica e ecológica, além de sua complexidade e vulnerabilidade frente a influência antrópica, onde se destacam as atividades portuárias. É razoável considerar que estas influências produzam modificações nos padrões ambientais da região, podendo resultar em modificações que interferem desde a biota até o transporte de sedimentos, e nos fluxos entre a região estuarina e a zona costeira adjacente. Essa possivel modificação no balanço sedimentar do Estuário da Laguna dos Patos, pode se refletir em frágeis feições presentes no estuário, como os pontais. O objetivo desse trabalho é avaliar o efeito das obras de modernização do Canal de Acesso ao Porto do Rio Grande sobre a dinâmica sedimentar do Pontal Sul, com base em técnicas de modelagem numérica e geoprocessamento. Também foi analisada a variação das áreas (erodidas e acrescidas) e da linha de costa do referido pontal. O estudo foi realizado utilizando imagens orbitais e o modelo numérico tridimensional TELEMAC-3D. Os resultados indicam que as obras de modernização do Porto do Rio Grande, alteraram as taxas de erosão e deposição no Pontal Sul, além de evidenciar uma tendência de crescimento longitudinal do pontal. Estes resultados são um indicativo do impacto da referida obra de modernização na dinâmica sedimentar do estuário da Lagoa dos Patos.

Palavras chave: Influência antrópica, erosão, deposição, portos, modelagem numérica

\footnotetext{
(a) Corresponding author, to whom correspondence should be addressed: <paulovictor_fjv@hotmail.com>

${ }^{\text {a }}$ Universidade Federal do Rio Grande (FURG) - Instituto Oceanográfico - IO - Laboratório de Oceanografia Física Costeira e Estuarina, Av. Itália s/ nº, CEP 96200-000
}

* Submission: 29 JUL 2014; Peer review: 27 AUG 2014; Revised: 14 FEB 2015; Accepted: 5 MAR 2015; Available on-line: 6 MAR 2015
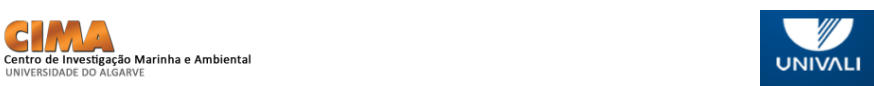


\section{Introduction}

Known as transition zones between the sea and the mainland, estuaries are recognized for their socio-economic and ecological importance as they receive nutrient contributions from the continent and the ocean, stimulating primary production and profitable fisheries (Miranda et al, 2002). The strategic location of estuarine areas promotes the growth of major urban centers in their surroundings, where the development of harbor activities can be highlighted. In this sense, estuaries are susceptive to natural and anthropogenic processes, being also subject to a combination of both impacts.

Brazil has more than 35 harbors along 8500 kilometers of coastline. Although they have different features (types of load, infrastructure and environmental conditions), they share common problems related to siltation, dredging operations and their consequences to the environment and water quality. Brazilian harbors are a logistical bottleneck for the national economy, limiting the Brazilian ability to compete internationally. Hence, in order to reduce the Brazilian harbor operational costs, investing in infrastructure is essential.

Recently, environmental and commercial demands, combined with the need of maintaining and expanding the current capacity of several Brazilian harbors, have led to strong investments. Particularly at Rio Grande
Harbor, financial resources were provided by the Brazilian Government to improve the harbor draft and safety navigation conditions. Both jetties located at the Patos Lagoon mouth (Figure 1) were extended (370 and $700 \mathrm{~m}$ ) and made convergent; also, the access channel was made progressively deeper with maximum depth of $18 \mathrm{~m}$ outside and minimum depth of $16 \mathrm{~m}$ inside the jetties. This modernization work finished in 2010 and is described in detail by Fernandes et al. (2012).

These investments were of great importance because Rio Grande Harbor is the only seaport with favorable geographical location in the South Atlantic, and is connected to all southern Brazil and several Latin American countries. It is expected, however, that alterations in the estuarine geomorphology will change the existing circulation patterns in the area, affecting the biota, the sediment transport patterns and the interaction between the estuary and the coastal zone.

Sand Spits are geomorphological features observed in micro-tidal areas under the influence of bidirectional wind along the main axis of the lagoon. Inside the Patos Lagoon, the predominant wind and wave direction and the initial shape of the lagoon are considered the most important factors for the genesis and evolution of these features (Zenkovich, 1967). Near the mouth of the Patos Lagoon estuary, where micro-tidal conditions are

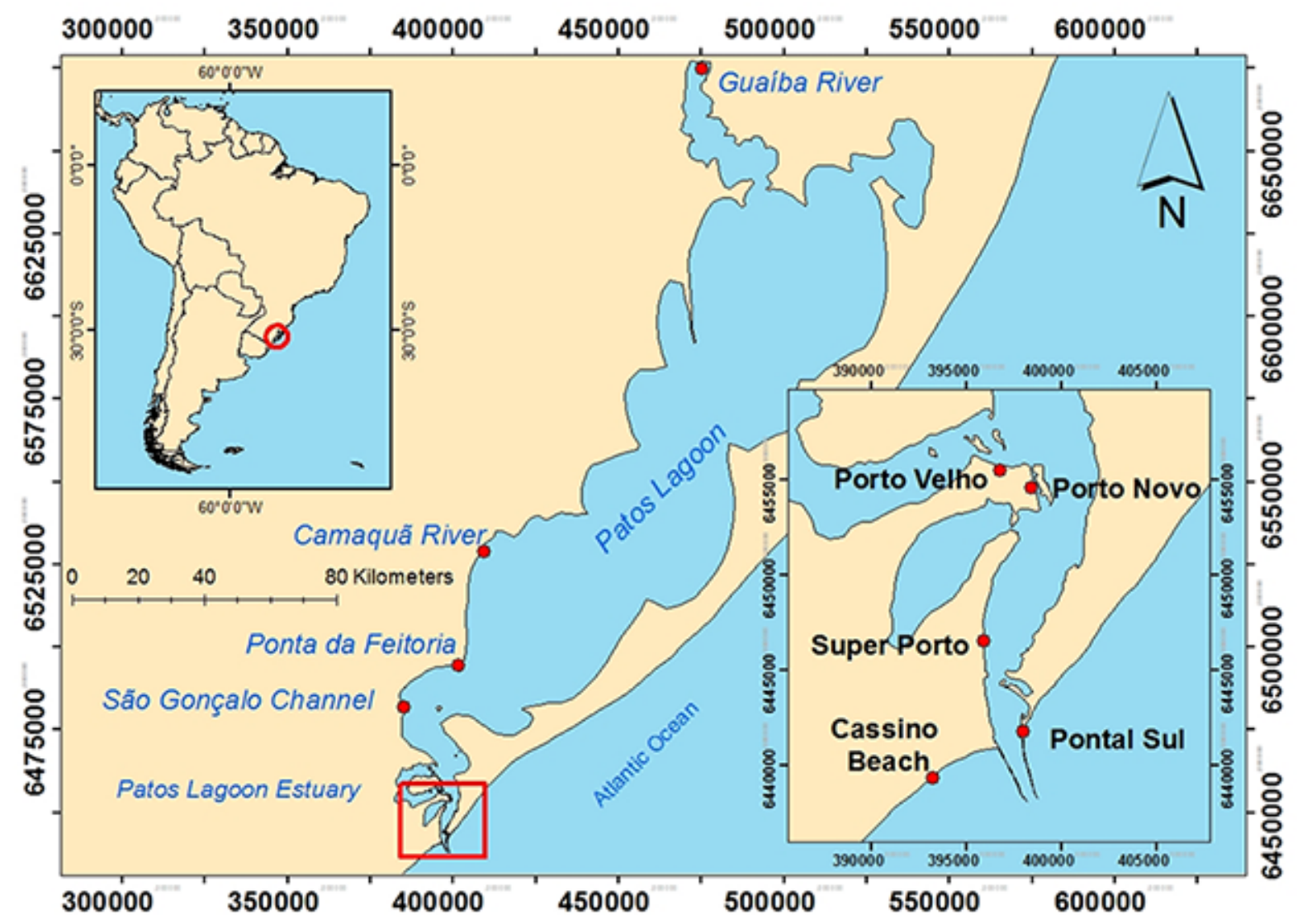

Figura 1 - Área de estudo.

Figure 1 - Study area. 
observed, the Pontal Sul sand spit constitutes a depositional feature resulting from the interaction between continental and oceanic processes (Antiqueira \& Calliari, 2004). Understanding the geomorphological evolution of these features in coastal regions subject to significant anthropogenic impacts is of great importance because their rapidly response to changes in the environment (Antiqueira \& Calliari, 2004). Thus, a study of the local hydrodynamics is crucial for understanding the sediment budget in the region.

Given the context, this paper aims to evaluate the effect of the modernization work carried out at Rio Grande Harbor access channel on the sedimentary dynamics of the Pontal Sul sand spit as an indicator of the anthropogenic contribution to the processes shaping the system.

\section{Study area}

The Patos Lagoon (Figure 1), located on the southernmost part of Brazil (between $30^{\circ} \mathrm{S}$ and $32^{\circ} \mathrm{S}$ ), is the largest choked coastal lagoon in the world (Kjerfve, 1986), being $250 \mathrm{~km}$ long and $40 \mathrm{~km}$ wide, covering an area of $10.360 \mathrm{~km}^{2}$. The lagoon is considered a shallow system with a mean depth of $5 \mathrm{~m}$ and higher depths occurring in the estuarine channels. The system is connected to the South Atlantic Ocean through a narrow channel, which is less than $1 \mathrm{~km}$ wide and about $18 \mathrm{~m}$ deep.

The Lagoon drains a basin of approximately $201,626 \mathrm{~km}^{2}$, being the Guaíba and Camaquã Rivers the main tributaries in the north and central lagoon, respectively (Figure 1). The hydrographic basin rivers have a midlatitude pattern: high discharge in late winter and early spring followed by low to moderate discharge through summer and autumn (Moller et al., 2001). The mean annual freshwater contribution in the north of Patos Lagoon is $2000 \mathrm{~m}^{3} \mathrm{~s}^{-1}$; seasonal variations can be observed from $700 \mathrm{~m}^{3} \mathrm{~s}^{-1}$ during summer (late December-March) up to $3000 \mathrm{~m}^{3} \mathrm{~s}^{-1}$ during spring (September-early December). Moller et al. (1996) observed river discharge peaks of 12,000 and $25,000 \mathrm{~m}^{3} \mathrm{~s}^{-1}$ during El Niño years.

The Patos Lagoon circulation is mainly controlled by a combination of setup and setdown driven by local winds and non-local wind action in the coastal region and by the river discharge in the north of lagoon (Fernandes et al., 2002; 2005; Moller et al., 1996). The wind action has an important role during low and moderate river discharge $\left(<3000 \mathrm{~m}^{3} \mathrm{~s}^{-1}\right)$. Moller et al. (2001) demonstrated that the NE wind causes a barotropic pressure gradient towards the ocean, resulting in a freshwater discharge onto the continental shelf. In contrast, SW wind causes an increase in the water level (Ekman transport) on the coast, causing the establishment of a barotropic pressure gradient toward the continent, resulting in a flood regime at the Patos La- goon. In opposition, this pattern does not occur during high river discharge episodes $\left(>4000 \mathrm{~m}^{3} \mathrm{~s}^{-1}\right)$ because the SW wind effect is overwhelmed by the river discharge, which produces a high pressure gradient towards the ocean. In this situation, the estuarine zone occurs at the adjacent coastal region (Moller \& Castaing, 1999).

The tidal signal in the region is mixed (mainly diurnal), having a mean range of $0.47 \mathrm{~m}$ (Moller et al., 2001); therefore, characterizing a microtidal system. The tidal effect is of secondary importance for the dynamics of the system, being restricted to the coastal region and the estuarine portion of the Patos Lagoon. The access channel acts like a filter damping the tidal signal as it moves up the estuary (Fernandes et al., 2004).

The morphological characteristics of the Patos Lagoon show a dominance of coarse sediment in the shallow areas and fine grains in the deeper ones, especially in the estuarine zone. The west margin of the Patos Lagoon is covered by medium to coarse sands (Martins et al., 1987), carried out mainly by the Camaquã River. At the east and north margins, the sediment is composed of fine sand from the coastal-marine depositional system.

The estuarine region, where the Rio Grande Harbor is located (Figure 1), occupies about 10\% of the Patos Lagoon area; characterized by an increase in cross section with the distance from the mouth (Möller et al, 2001). The Lagoon and the estuary are separated by a morphological step formed by sandbanks situated around the region called Ponta da Feitoria (Figure 1).

Apart from the contribution of the main Lagoon, the São Gonçalo Channel is an important source of sediment to the Patos Lagoon estuary (Hartmann et al., 1990). The sedimentology of the estuarine area is more diverse than in the lagoon, presenting sand in the shallow banks and a combination of silt and clay in the deeper areas (Calliari et al., 2009).

\section{Materials and methods}

The study of the dynamics of geomorphological features, sand spits included, can be carried out based on direct observations in the field, remote sensing and application of numerical models. Each of these techniques has advantages and disadvantages and is complementary to each other. This study is based on remote sensing and numerical modeling techniques.

\subsection{Digital processing of images}

Orbital images from the Quickbird satellite sensor (Digital Globe), acquired from the IFRS (InstitutoFederal do Rio Grande do Sul) database, with a panchromatic spatial resolution of $0.61 \mathrm{~m}$, in three bands of colors (green, red and blue), for the years of 2004, 
2007, 2009 and 2012 were used to construct the recent migratory behavior of the sand spit area.

The images were georeferenced using $\operatorname{ArcGis}{ }^{\circledR 9} 9.3$. An orbital image already registered with ground control points (GCP) was used as base map in the correction process; afterwards, the images were projected to the WGS84 - UTM Zone 22S projection. The choice of ground control points corresponds to an important stage of the work. The accuracy applied to extract the shoreline is dependent upon the accuracy applied in the identification the GCPs. At least 15 control points were distributed in the regions close to the sand spit for each image.

\subsubsection{Error inherent to the photogrammetric process}

In order to measure inaccuracies resulting from photogrammetric process, the standard image geospatial positioning proposed by the US Geographic Data Committee (FGDC - STD, 1998) was adopted. This standard uses the residual error (Root Mean Square - RMS) to quantify the average error of the georeferencing process (Table1).

Table 1 - RMS values calculated for each image composition.

Tabela 1 - Valor de RMS calculado para cada composição da imagem

\begin{tabular}{c|c}
\hline Years & Mean Squared Error $(\mathbf{c m})$ \\
\hline $\mathbf{2 0 0 4}$ & 1.1509 \\
$\mathbf{2 0 0 7}$ & 1.0208 \\
$\mathbf{2 0 0 9}$ & 0.9824 \\
$\mathbf{2 0 1 2}$ & 1.0345 \\
\hline
\end{tabular}

\subsubsection{Extraction of shoreline and area calculation for each image}

The shoreline determination and its dynamical behavior over time are essential for numerous activities related to research, engineering and planning. As the shoreline is vulnerable to accretional and erosional processes, the Change Polygon Method (Smith \& Cromley, 2012) was used to evaluate the shoreline variation in this study. The erosion process is responsible for the loss in sedimentary areas when compared to other years, whist the accretion process is related to the increase of the beach strip caused by sediment accumulation.

Due to the difficulty to detect the shoreline, its extraction was done using a constant indicator in each image called the high-water line (maximum run-up of the water). Among all other possible indicators of shoreline reported by Boak \& Turner (2005) the wet/dry interface on a sand beach proved to be the most consistent one.

Based on the method proposed by Smith \& Cromley (2012), from two distinct coastlines previously vec- torized, one can extract the eroded and/or increased area by the generation and subtraction of polygons. Thus, from the intersection of two coastlines, a series of polygons is created so that they represent the regions where accretion and/or erosion process are occurring. By analysing the changes in the polygon, it is possible to quantify the variation between two shorelines. Hence areas where both positive and negative changes occur can be calculated from the decomposition of this complex polygon into a series of simpler sub-polygons.

Vectorised files (shapefiles) were generated using ArcMAP 9.3. The vectorised shoreline in the images was used to generate and calculate the polygons. To calculate the spit area variation rates, in every interval under analysis, the polygon that resulted from the oldest date was subtracted from the one that resulted from the most recent one. As a result, the final area value, in square meters, represents the eroded/accreted area in that period.

\subsection{Computational modeling}

The hydrodynamic model used in this study was the TELEMAC-3D, developed by EDF - Laboratoire National d'Environnement et Hydraulique Company Electricite de France (EDF), combined with the sediment transport model SediMorph, developed by Federal Waterways Engineering and Research Institute and the Institute für Wasserwesen from the University of the German Armed Forces, Munich.

The TELEMAC-3D solves the Navier-Stokes equations considering local variations on the free surface of the fluid using the advection-diffusion equations for transporting tracer concentrations (temperature, salinity or suspended sediment). The hydrostatic pressure and Boussinesq approximations were used to solve the momentum equations (Hervouet, 2007).

The SediMorph model is a tri-dimensional morphodynamic and fractionated sediment transport model (Malcherek et al., 2005). This model calculates the bed roughness as a function of grain size and shape, the bottom shear stress as function the roughness and intensity of the flow, the rates of bottom transport, the rates of erosion and deposition and the bed evolution.

The rate of erosion is calculated according the formulation of Partheniades (1965):

$$
\emptyset_{\text {ero }}=\left\{\begin{array}{rr}
M_{\text {res }}\left(\tau_{b} / \tau_{c e}-1\right) & \text { for } \tau_{b} \leq \tau_{c e} \\
0 & \text { for } \tau_{b}<\tau_{c e}
\end{array}\right.
$$

where, is the rateof erosion and is a shear stress. The formulation assumes that the sediment is eroded when the bottom shear stress is greater than the critical shear strain.

The rate of deposition is based on the Partheniades (1965) formulation: 


$$
\emptyset_{\text {dep }}=\left\{\begin{array}{rr}
W_{c} C z\left(1-\tau_{b} / \tau_{c d}\right) & \text { for } \tau_{b} \leq \tau_{c d} \\
0 & \text { for } \tau_{b} \geq \tau_{c d}
\end{array}\right.
$$

where $\mathrm{C}$ is the concentration of sediments along the water column, is the bottom shear stress, and is the critical shear strain for the deposition of sediments.

The SediMorph model was coupled to the hydrodynamic model TELEMAC-3D by Marques et al., 2010. Within the coupling, the hydrodynamic model calculates the flow velocity, flux of material in suspension and deposition flux whereas the morphodynamic model calculates sediment transport near the bottom, erosion flux, updating the friction with the new bed characteristics and bathymetry. The main parameters considered are presented in Table 2.

Table 2 - Parameters used in the models set-up.

Tabela 2 - Parâmetros usados para a calibração do modelo

\begin{tabular}{c|c} 
Time step & 90 seconds \\
Coriolis coefficient & $-7.70 \times 10^{-5} \mathrm{~N} \mathrm{~m}^{-1} \mathrm{~s}^{-1}$ \\
Horizontal turbulence model & Smagorinsky \\
Vertical turbulence model & Mixing length (Jet) \\
Scale mixing length & $10 \mathrm{~m}$ \\
Law of bottom friction & Nikuradse \\
Coefficient of Wind influence & $6 \times 10^{-6} \mathrm{~N} \mathrm{~m}^{-1} \mathrm{~s}^{-1}$ \\
Settling deposition law & Van Leuseen \\
Bottom transport model & Hunziker \\
Erosion law & Quadratic \\
Sediment transported in & Fine Silt \\
suspension & \\
\hline
\end{tabular}

The two coupled hydrodynamic and morphodynamic simulations, both 225 days length, were performed considering exactly the same initial and boundary conditions. In order to analyze the results in a comparable way, each simulation was carried out based on a different numerical mesh (Figure 2), one representing the

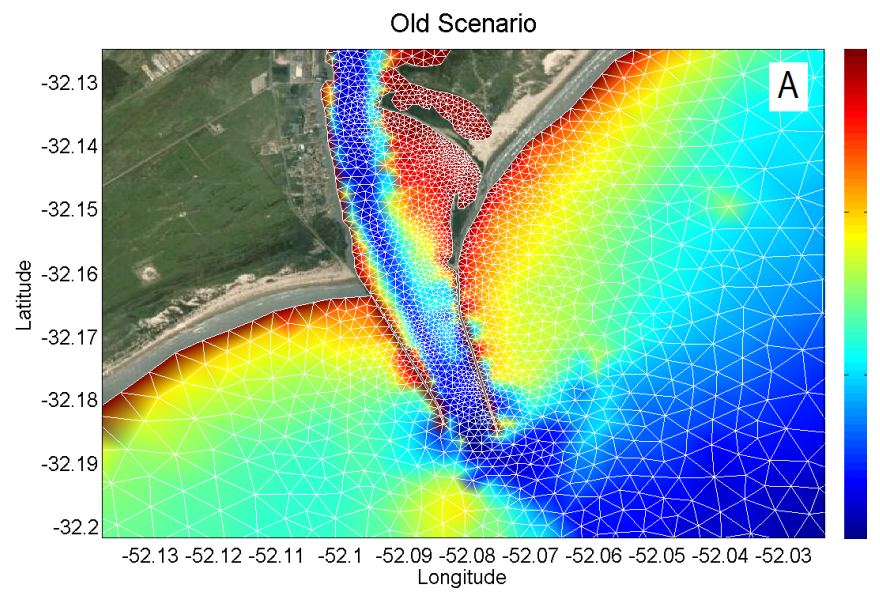

Figure 2 - Mesh with the old (A) and actual (B) scenario.

Figura 2 - Malha com os cenários Antiga (A) e Atual(B) configuration before (Figure 2A) and another after the modernization work (Figure 2B). The simulations did not include the wave effect.

A brief description of the initial and boundary conditions used in the simulations is provided in this section, while more details are presented in Marques et al. $(2009,2010)$.

Initial salinity and temperature fields were obtained from the OCCAM Project (Ocean Circulation and Climate Advanced Modeling Project), and prescribed in three dimensions over the entire domain (Figure 3). In the coastal area, salinity and temperature fields (OCCAM project) represent the influence of the $\mathrm{La}$ Plata river discharge over the SBS (Southern Brazilian Shelf) and the Brazil Current (BC) along the continental shelf at the northern oceanic boundary. Water levels were set to $0.4 \mathrm{~m}$, which is about the mean value of the tide in the study region; finally, null velocity fields were prescribed in the entire domain. At the continental boundaries, river discharge from the National Water Agency's page (www.ana.gov.br, ANA) was prescribed for the main tributaries in the studied area (Camaquã and Guaíba rivers). At the oceanic boundary, amplitude and phase data for the major five tidal components $\left(\mathrm{K}_{1}, \mathrm{M}_{2}, \mathrm{~N}_{2}, \mathrm{O}_{1}\right.$ and $\left.\mathrm{S}_{2}\right)$, obtained from the Grenoble Model FES95.2 (Finite Element Solution - v.2004) were prescribed.

The model surface boundary layer was forced with time and space varying winds from the NOAA Reanalysis database (www.cdc.noaa.gov/cdc/reanaly-sis) with 1.75 degrees of spatial resolution at 4 hours intervals. Data covering from $25^{\circ} \mathrm{S} 42^{\circ} \mathrm{W}$ to $38^{\circ} \mathrm{S} 55^{\circ} \mathrm{W}$ was collected and interpolated using a cubic in-terpolation to a $1 \mathrm{~km}$ resolution mesh. Afterwards, for each nodal point of the mesh, the meridional and zonal wind components of the wind were extracted and the resulting vector was computed by the model using a constant coefficient of wind influence of $6 \times 10^{6}$.

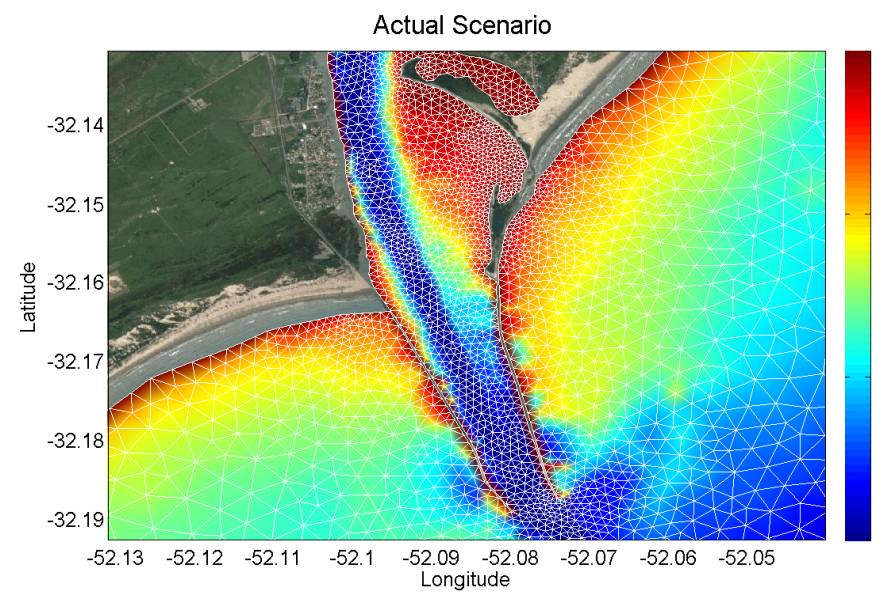


The initial conditions for SediMorph were prescribed considering initial zero concentration of suspended solids in the entire domain. Boundary conditions were considered for the concentrations of suspended solids along the continental open boundaries, where the river discharge is prescribed. Constant values of concentration of suspended solids were considered: $0.5 \mathrm{~kg} \mathrm{~m}^{-3}$ for the discharge of the Guaíba River and $0.3 \mathrm{~kg} \mathrm{~m}^{-3}$ for the Camaquã River (Niencheski \& Windom, 1994). Initial bottom sediment distribution was prescribed using measurements taken between 1975 and 1979 in the Patos Lagoon and Estuary (Toldo, 1994). The classes of sediments prescribed were distributed as fine silt, fine sand and coarse sand (Figure 3B) in the lagoon and estuarine region. At the coastal area, the bottom was defined as fine sand (Figure 3B).

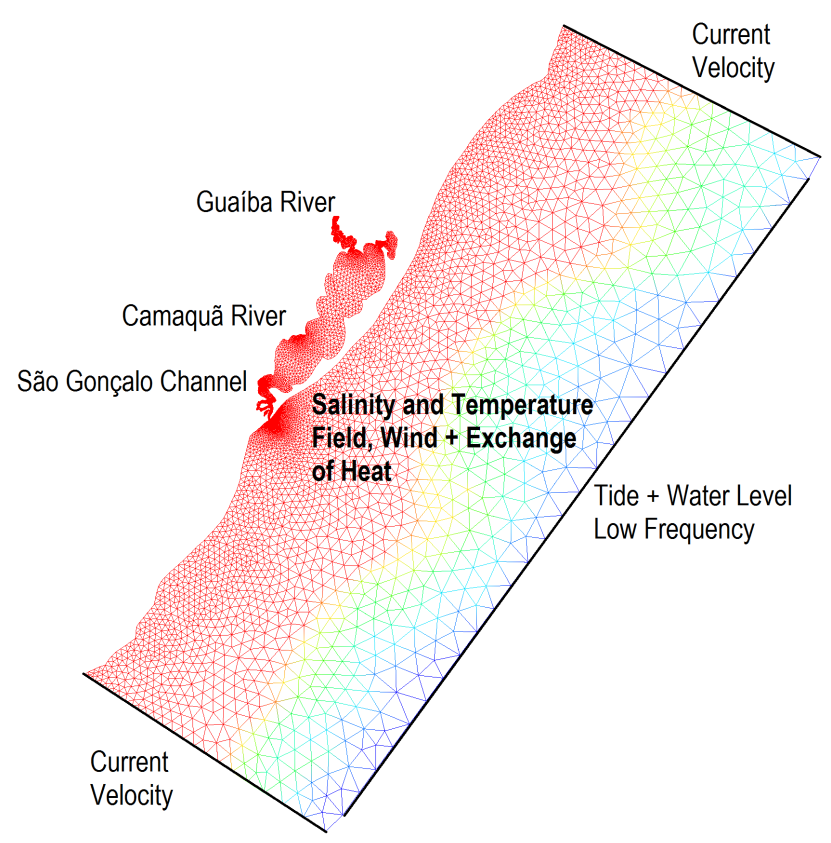

Figure 3 - Boundary Conditions for TELEMAC-3D model Figura 3 - Condições de Contorno do modelo TELEMAC-3D

The calibration and validation of hydrodynamic model (TELEMAC3D) and morphodynamic model (SediMorph) coupling was presented in detail by Marques et al. (2010), where the authors compared the model results with hydrodynamic field data and suspended sediment concentrations extracted from satellite images. Results from the calibration and validation tests indicated that the coupled models well reproduce the behavior of the system.

\section{Results}

\subsection{Sand spit morphological variations}

Variations on the shoreline position and on the sand spit area were analyzed from 2004 to 2012 . In order to quantify the behavior of the erosion and accretion process before and after the modernization work carried out in Rio Grande Harbor access channel, the time interval was fractionated over 3 years periods. Also, an overall analysis of the 9 years period was presented.

Figure 4 presents the Pontal Sul sand spit eroded and increased areas and the balance between them for the period between 2004 and 2012. Results presented in Figure 4A indicate that for the period between 2004 and 2007 (before Rio Grande Harbor modernization work) the Pontal Sul sand spit exhibited an erosive behavior with a reduction of $26550 \mathrm{~m}^{2}$ in the total area. This result corresponds to an averaged annual erosion rate of approximately $8850 \mathrm{~m}^{2} /$ year. Figure $5 \mathrm{~A}$ shows the eroded (red) and the increased (yellow) areas for the same period. This analysis indicates that the Pontal Sul sand spit becomes slender and longer with time. Knowing that the perimeter of the sand spit in the earliest period (2004) was $2643.46 \mathrm{~m}$, the mean reduction of the shoreline observed in this period was $5.46 \mathrm{~m}$, resulting in an annual averaged erosion rate of $1.82 \mathrm{~m} /$ year.

Results presented in Figure 4B indicate that for the period between 2007 and 2009 (the period over which the modernization work occurred), the Pontal Sul sand spit trend was still erosive (eroded area of $29370 \mathrm{~m}^{2}$ ), with an averaged annual erosion rate of $14685 \mathrm{~m}^{2} /$ year. Figure 5B shows the eroded (red) and the increased (yellow) areas for the period. Results indicate that the Pontal Sul sand spit continues to grow in the northsouth direction. The perimeter of the shoreline in 2007 was $3753.29 \mathrm{~m}$, and the mean reduction of the shoreline observed in this period was $5.69 \mathrm{~m}$, resulting in an annual average erosion rate of $2.48 \mathrm{~m} /$ year.

Results presented in Figure 4C indicate that for the period between 2009 and 2012 (the modernization work was finished in 2010), a reduction in the erosion rates, but not enough to change the erosive tendency of period. The total area eroded was $19110 \mathrm{~m}^{2}$, with an average annual rate of $9555 \mathrm{~m}^{2} /$ year. Figure $5 \mathrm{C}$ shows the eroded (red) and the increased (yellow) areas for the period, which indicates a decrease in the erosion tendency when compared to the previous periods. The perimeter of the shoreline in 2009 was $3004.93 \mathrm{~m}$, and the average reduction of the shoreline observed in this period was $2.70 \mathrm{~m}$, resulting in an annual mean of $0.9 \mathrm{~m} /$ year.

The overall balance over time $(2004-2012)$ indicated that Pontal Sul sand spit eroded area was higher than the increased area (Figure 6). The total eroded area was $64750 \mathrm{~m}^{2}$, with an average annual erosion rate of $8093 \mathrm{~m}^{2} /$ year. Figure 7 strengthens this result showing the eroded (red) and the accreted (yellow) areas for the whole period. The initial perimeter of the shoreline in 2004 was $2643.46 \mathrm{~m}$, and the average reduction of the 

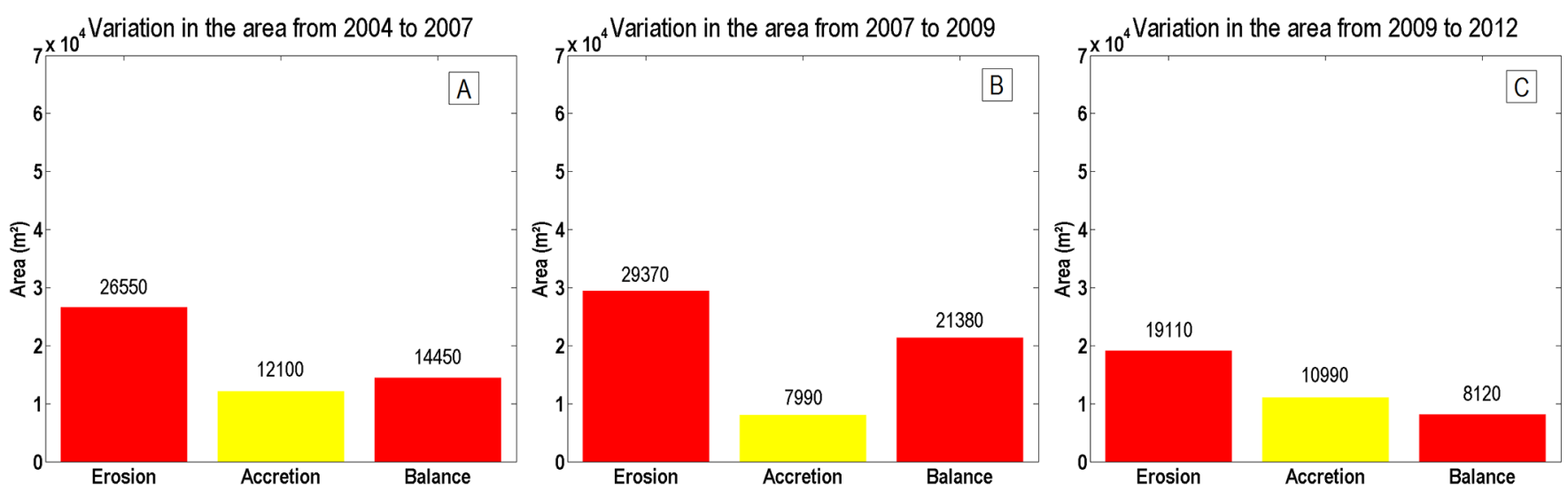

Figure 4 - Pontal Sul eroded and increased area and the balance between them for A) 2004 to 2007, B) 2007 to 2009 , C) 2009 to 2012

Figura 4 - Área erodida e acrescida do Pontal Sul, e o balanço entre elas entre A) 2004 e 2007, B) 2007 e 2009, C) 2009 e 2012.
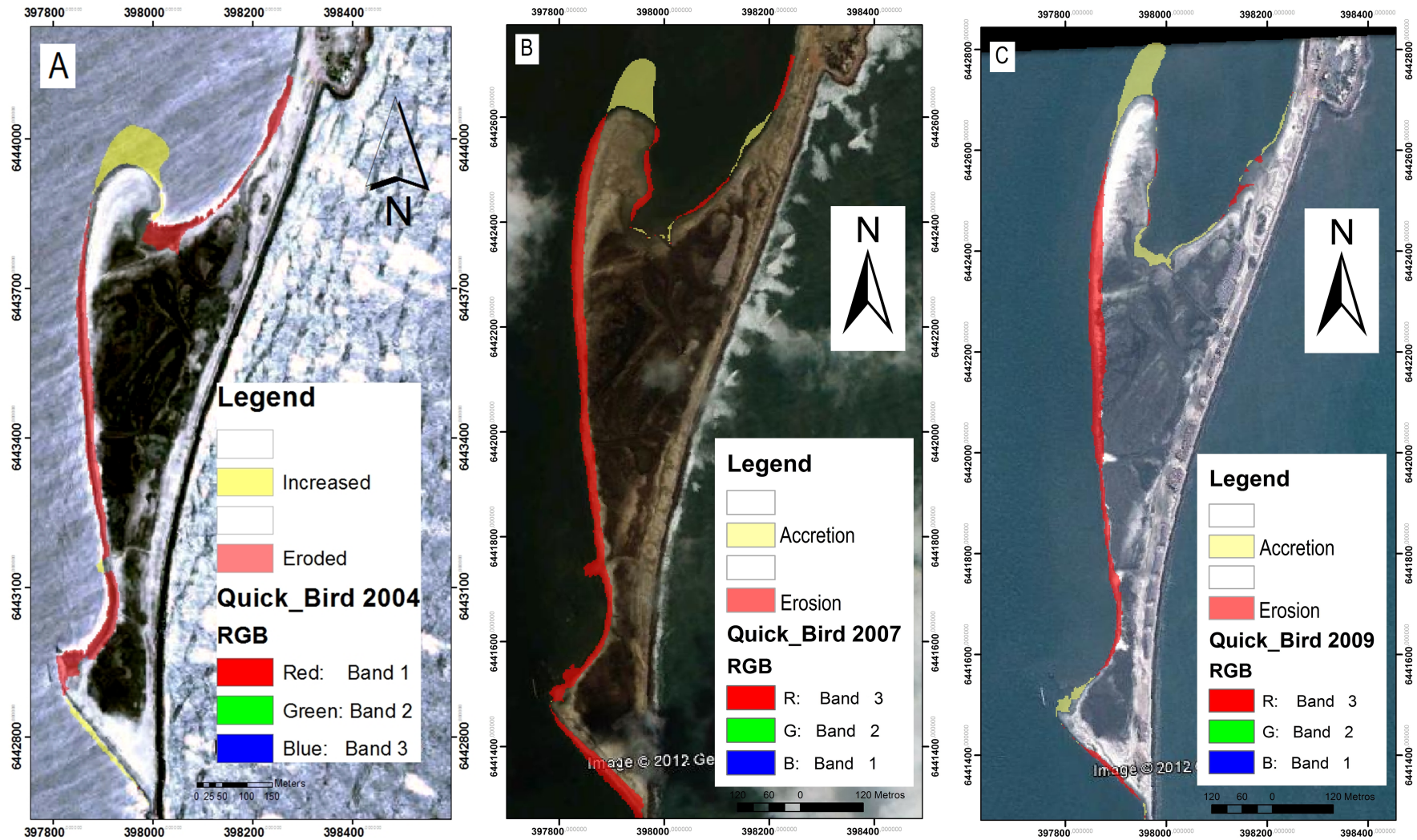

Figure 5 - Pontal Sul eroded and increased area and the balance between them between 2004 and 2012.

Figura 5 - Área erodida e acrescida do Pontal Sul, e o balanço entre elas entre 2004 e 2012.

shoreline observed in this period was $16.88 \mathrm{~m}$, resulting in an annual erosion rate of $2.11 \mathrm{~m} /$ year. Thus, the overall analysis of the studied period indicated that the predominant process is the erosion of the sand spit west margin; although, accretion also occurs in specific areas, promoting the longitudinal growth of the sand spit.

\subsection{Hydrodynamic Modeling}

In order to compare the hydrodynamics and sediment dynamics of the Patos Lagoon estuary before and after the modernization work carried out at Rio Grande
Harbor access channel, numerical simulations were carried out using both domains (see Figure 2) with exactly the same initial and boundary conditions.

\subsubsection{Residual Ebb Current Velocity}

The dominance of $\mathrm{NE}$ winds over the region induces the dominance of ebb currents in the estuarine region. The mean ebb current velocity calculated by the numerical model for both scenarios, for the simulated period, is presented in Figure 8. The highlighted area along the sand spit shows a reduction in the mean ebb 


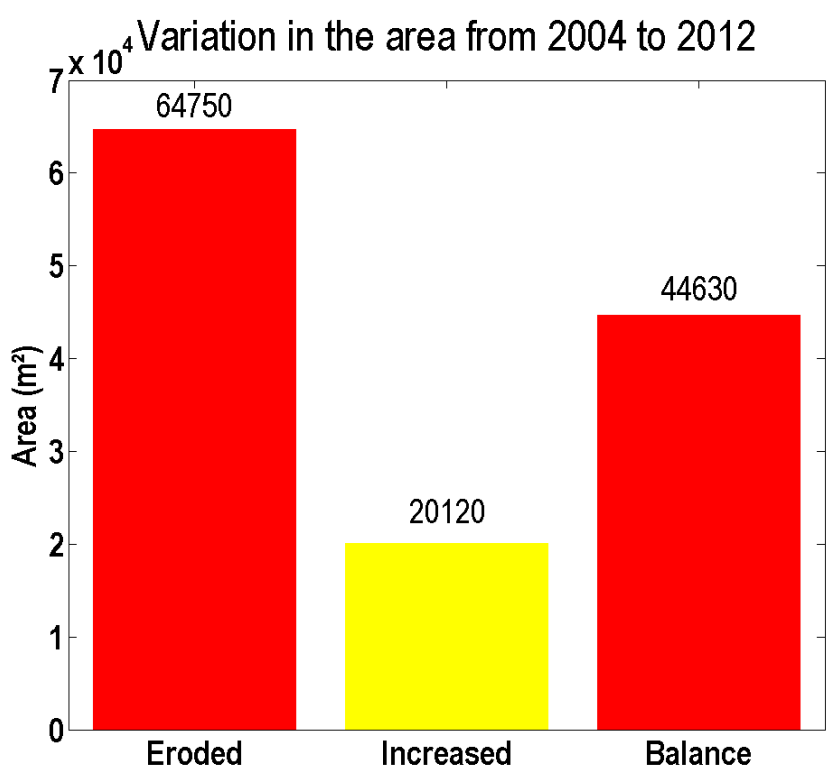

Figure 6 -Evolution of the sand spit area between 2004 and 2012 superimposed on a QuickBird image from 2004,and its spectral composition (bands).

Figura 6 - Evolução da área do Pontal Sul entre os anos de 2004 e 2012, sobreposta a uma imagem QuickBird do ano de 2004, com suas composições espectrais (Bandas).

current velocity when the present configuration of Rio Grande Harbor access channel was taken in account. Therefore, the model results confirm the tendency observed in section 4.1, suggesting that before the modernization work the ebb currents that tended to erode the west margin of the sand spit were stronger. Modeling results suggest that after the work finished, the erosion potential was reduced by the reduction of the mean ebb current velocity along the west margin of the spit. Furthermore, modeling results confirm the growing trend observed in the northern part of the sand spit because the recirculation created in this region after the modernization work (highlighted in Figure 8B) appears to keep the sediment trapped in the area.

\subsection{Morphodynamic modeling.}

\subsubsection{Bottom Shear Stress}

Figure 9 presents the mean bottom shear stress calculated by the model using the old (Figure 9A) and new (Figure 9B) configuration of Rio Grande Harbor access channel. Warm (cold) colors indicate higher (lower) values.

Results indicate that there was an overall reduction in the bottom shear stress in the main channel when considering the new configuration of Rio Grande Harbor access channel. A similar behavior was also observed in the area close to the Pontal Sul west margin central part (Figure 9B). These results corroborate the erosion tendency decrease observed in the satellite images.

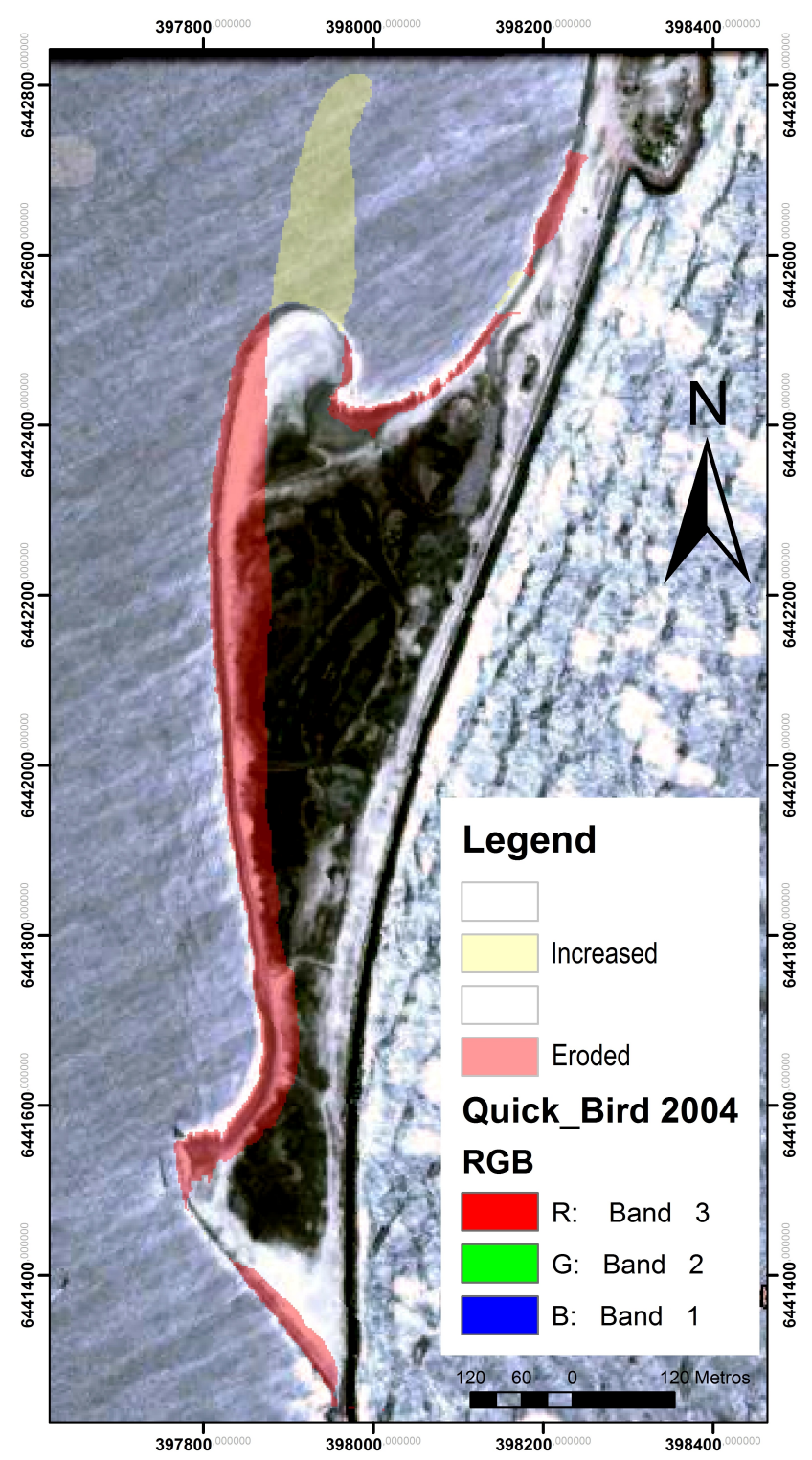

Figure 7 - Evolution of the sand spit area between A) 2004 and 2007 (superimposed on a QuickBird image from 2004); B) 2007 and 2009 (superimposed on a QuickBird image from 2007); C) 2009 and 2012 (superimposed on a QuickBird image from 2009), with its spectral composition (bands).

Figura 7 - Evolução da área do Pontal Sul entre A) 2004 e 2007 (sobreposta a uma imagem QuickBird de 2004); B) 2007 e 2009 (sobreposta a uma imagem QuickBird de 2007); C) 2009 e 2012, sobreposta a uma imagem QuickBird de 2009), com suas composições espectrais (Bandas).

\subsubsection{Mean Erosion and Deposition Fluxes}

Figure 10 presents the mean deposition flux calculated by the morphodynamic model considering the old (Figure 10A) and new (Figure 10B) configuration of Rio Grande Harbor access channel. Warm (cold) colors indicate higher (lower) values.

Modelled results indicate that there was an overall increase in the mean deposition flux along the main 

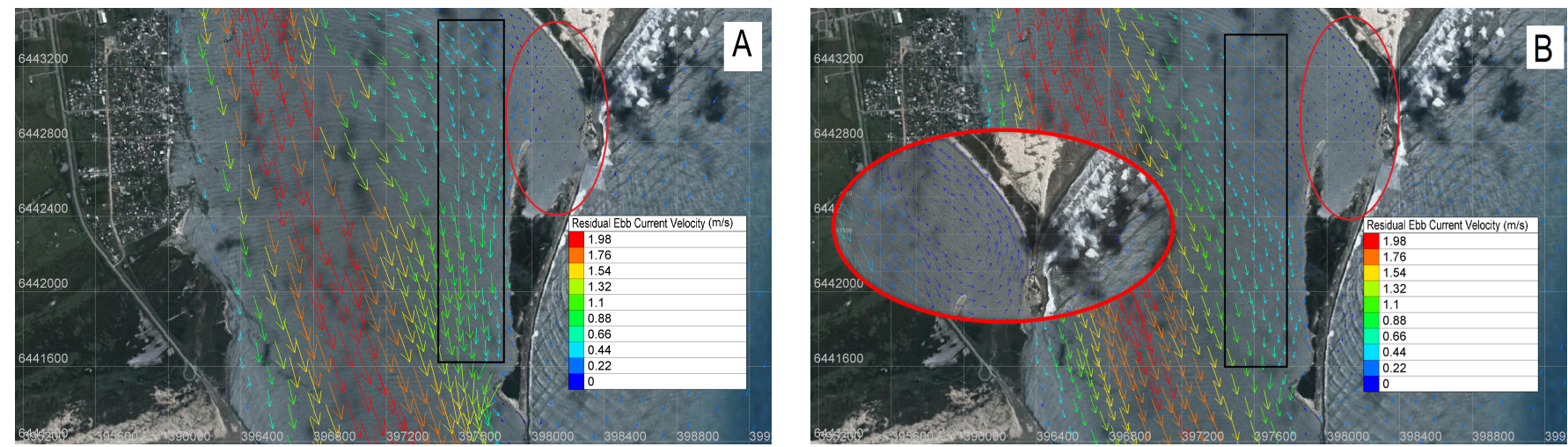

Figure 8 - Mean ebb current velocity calculated by the model for the old (A) and actual (B) scenario, superimposed on a QuickBird image from 2012. A highlight is given for the recirculation observed at the north of Pontal Sul.

Figura 8 -Velocidade média de vazante calculada pelo modelo para o cenário antigo (A) e atual (B), sobreposta a uma imagem QuickBird do ano de 2012. Em destaque a recirculação observada ao norte do Pontal Sul.
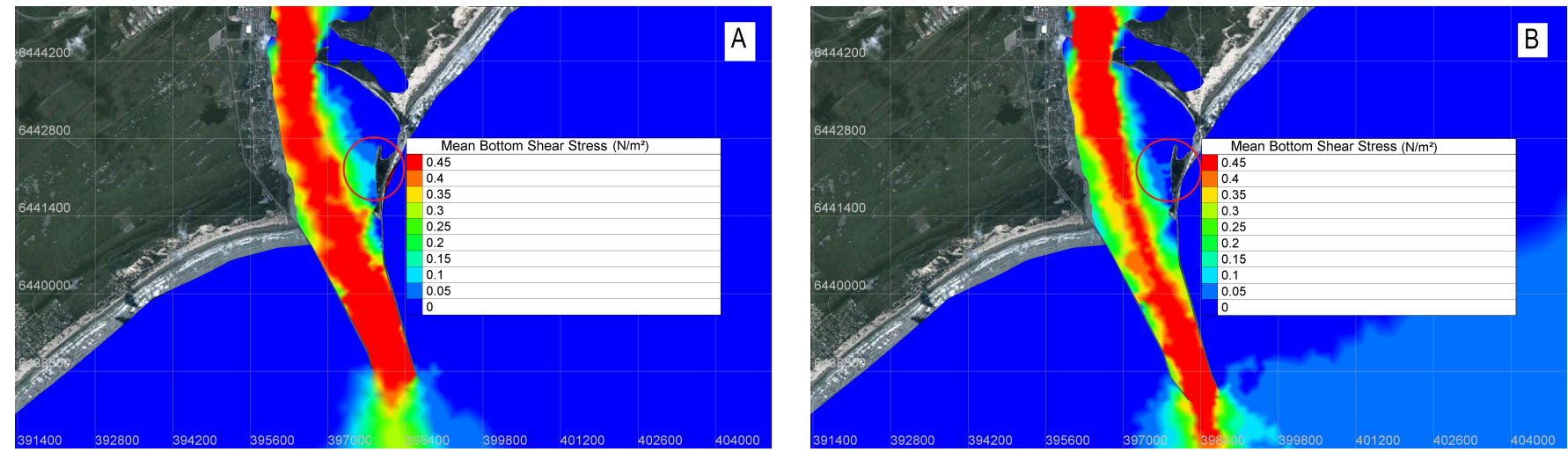

Figure 9 - Bottom shear stress calculated by the morphodynamic model considering the old (A) and new (B) scenarios, superimposed on a QuickBird image from 2012.

Figura 9 - Tensão de cisalhamento de fundo calculada pelo modelo morfodinâmico para o cenário antigo (A) e para o cenário atual (B), sobreposta a uma imagem QuickBird do ano de 2012.
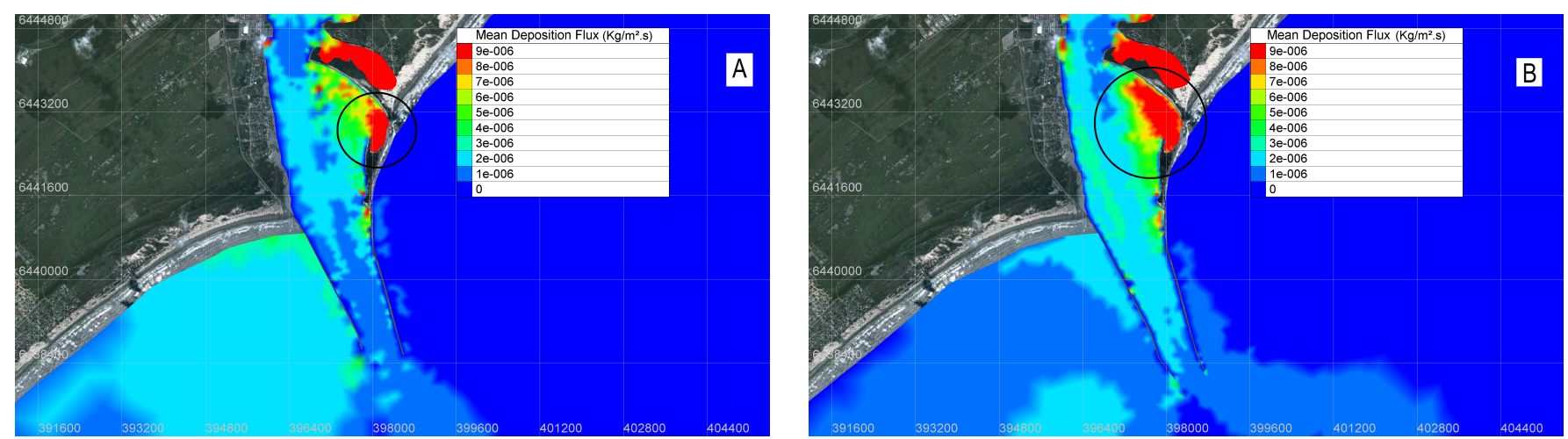

Figure 10 - Mean deposition flux calculated by the morphodynamic model for the old (A) and new (B) scenarios. Results superimposed on QuickBird image from 2012.

Figura 10 - Fluxo médio de deposição calculado pelo modelo morfodinâmico para o cenário antigo (A) e novo (B). Resultados sobrepostos imagem QuickBird do ano de 2012. 

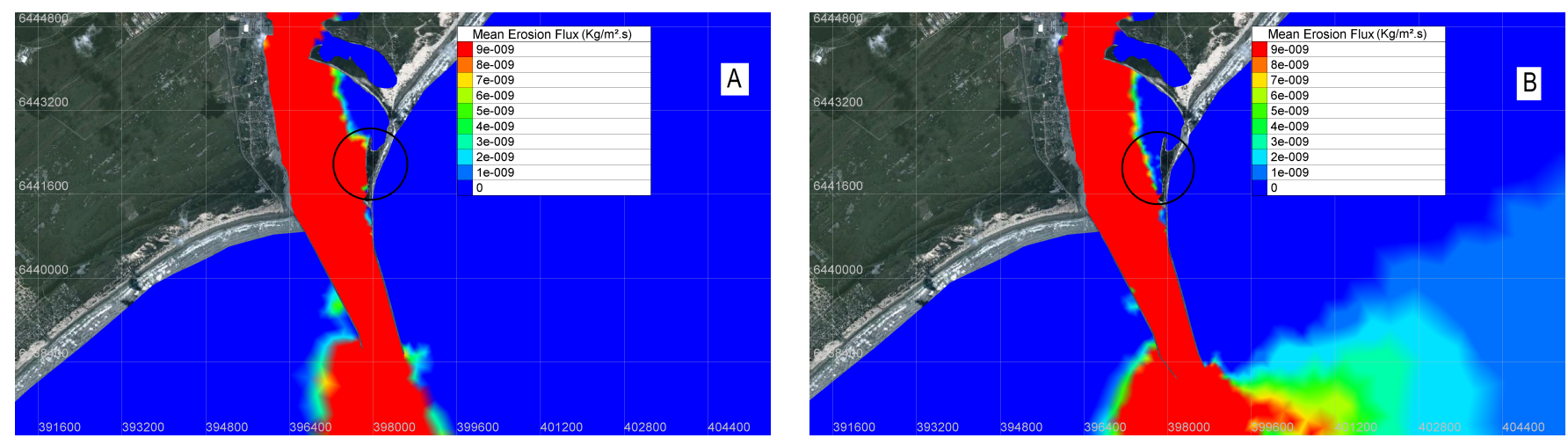

Figure 11 - Mean erosion flux calculated by the morphodynamic model for the old (A) and new (B) scenarios. Results superimposed on QuickBird image from 2012.

Figura 11 - Fluxo médio de erosão calculado pelo modelo morfodinâmico para o cenário antigo (A) e novo (B). Resultados sobrepostos imagem QuickBird do ano de 2012.

channel when considering the new configuration (Figure 10B) of Rio Grande Harbor access channel. Moreover, an increase in the mean deposition flux was observed at the north of the Pontal Sul sand spit. As a result, these results are in accordance with the increased deposition observed in this area in the satellite images (Figure 5C).

The Figure 11 presents a similar analysis for the modelled mean erosion flux. Although results do not indicate expressive differences for the main access channel, a decrease in the mean erosion flux is evident along the Pontal Sul west margin when considering the new scenario (Figure 11B). These results are in accordance with the decrease in the erosion tendency observed in satellite images after the modernization work (Figure 5C).

\subsubsection{Bed Evolution}

The bed evolution calculation takes in account the balance between the deposition flux and the erosion of the suspended sediment and the transport of material

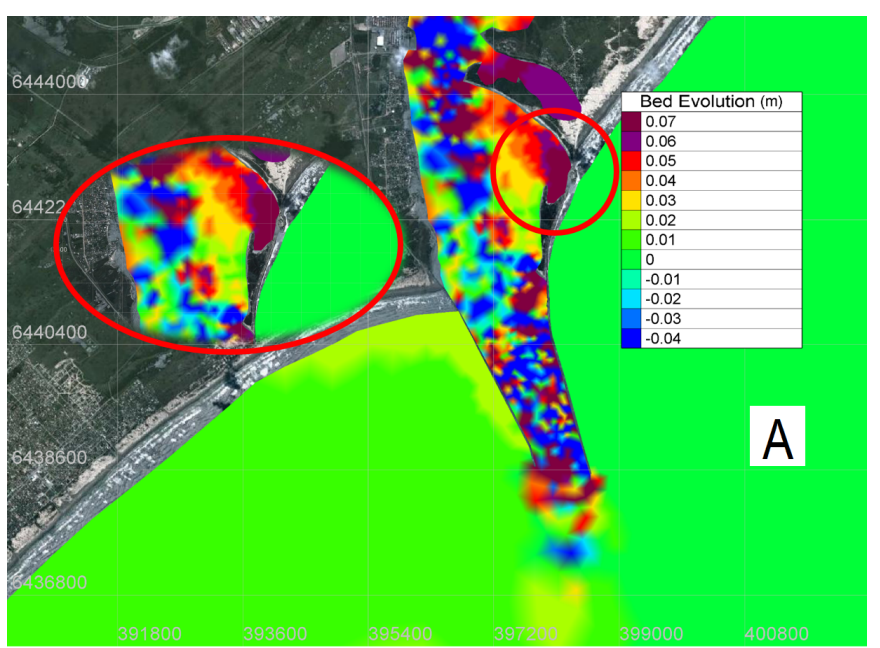

informed as initial condition for the model. The comparison between the bed evolution results calculated by the morphodynamic model for the old (Figure 12A) and new (Figure 12B) scenarios indicate significant differences in the north of the Pontal Sul region. It is evident that after the modernization work (Figure 12B) the material deposition in the sand spit area is favored.

Results presented in this study were consistent and of great potential for future applications and research. However, some considerations should be made in relation to the advantages and disadvantages of the methodologies employed and, also, regarding suggestions for the continuity of the present study.

The sediment transport study in coastal regions can be done by means of field data collection, remote sensing and numerical modeling. Each of these methods has advantages and disadvantages in relation to operational costs, logistics involved and complexity of application. In this study, both methods considered (remote sensing and numerical modelling) were of low cost and fairly

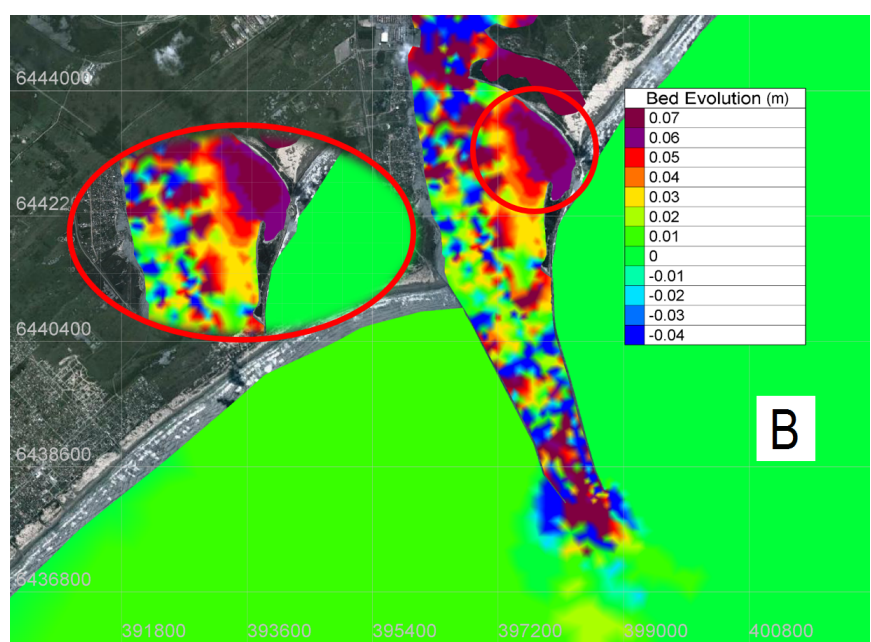

Figure 12 - Bed Evolution calculated by the model for the old (A) and new (B) scenarios superimposed on QuickBird image from 2012.

Figura 12 - Evolução do fundo calculada pelo modelo morfodinâmico para o cenário antigo (A) e atual (B), sobreposta numa imagem QuickBird do ano de 2012. 
simple logistics and at the same time providing good spatial and temporal resolution results to subsidize analysis. The consistency of both methodologies was validated by the convergence between the results on the observed and modelled variations in the sand spit shoreline resulting from the erosion and deposition balance.

\section{Discussion}

Sedimentary transport studies are usualy accomplished on field-based approaches, remote sensing techniques, and/or numerical modeling. The present study achieved relevant results linking both remote sensing and numerical modeling techniques. Antiqueira \& Calliari (2004) studied the dynamics of the Pontal Sul sand spit between 1947 - 2003; during this period, the authors observed alternating periods of accretion and erosion promoting variations in the feature, resultig in a net growth of $154 \%$ in spit area anf increase of $304.4 \mathrm{~m}$ in its longitudinal axis (N-S). The present study corroborates to the dynamic behavior of the Pontal Sul spit between 2004 to 2012, which presented tendency of erosion in the southern and central parts and of accretion in the northern part. However, based on the satellite images and in the modelled results, it was evident that the Rio Grande Harbor modernization seemed to change the expected patterns by reducing the erosion tendency along the west margin of the spit and increasing the deposition tendecy in the northern area. Moreover, it was evident that changes in mean ebb flow, which is predominant in the area (Moller et al., 2001), was the mechanism responsible for the observed alterations in the erosion and deposition fluxes, as explained by Partheniades (1965).

Lumborg \& Pejrup (2005) described a similar mechanism in the estuary of Lister Dyb, between Denmark and Germany. The authors used numerical modeling techniques to simulate the transport of sediment in the region, observing that the current velocity and shear stress were the main responsible for the remobilization of sediments, which would eventually reach the regions of low energy and deposit.

The effect of anthropogenic contributions in the dynamics of costasl systems was also mentioned by Lorenzo et al. (2007). The authors studied a sand spit system in Spain and observed that hydrodinamic parameters such as current velocity and tidal range, as well as morphodynamic parameters, were affected by an anthropogenic contribution, resulting in changes in the accretion trend during the studied period. More recently, Zaromskis \& Gulbinskas (2010) observed that the progressive dredging carried out at Klaipida harbor changed the local sediment dynamics, affecting the maintenance of the Curonian Spit due to the deficit of sediment supplement.

\section{Conclusions}

The idea of studying geomorphological changes of specific coastal features to infer changes in the dynamics of coastal systems resulting from anthropogenic contributions in coastal environments proved to be a valuable strategy. The combination between remote sensing information and numerical modeling for specific scenarios proved to be a low cost method with high spatial resolution. Thus, the combined methodology was efficient in evaluating the effect of the modernization work carried out at Rio Grande Harbor access channel on the sedimentary dynamics of Pontal Sul sand spit as an indicator of the anthropogenic contribution to the dynamics of the system.

The modernization work carried out in the access channel to Rio Grande Harbor did change the overall sediment dynamics of the system. Specifically for the Pontal Sul spit, it is possible to infer that this feature tends to become more slender and longer within time due to the reduction in the erosion tendency observed along the west coast of the spit and the less intense recirculation pattern established at the northern end.

These preliminary results also suggest that siltation in the main channel increased due to the modernization work. Therefore, it is essential to recognize the importance of carrying out the adequate investigation of the environmental impacts of such kind of coastal work before its execution.

\section{Acknowledgments}

The authors would like to express their gratitude to FINEP for sponsoring the TRANSAQUA Project (www.transaqua.furg.br), contract 01.11.0141.01, and to CNPq trough contracts 551436/2011-5 (EHF) and 308274/2011-3 (EHF).

\section{References}

Antiqueira, J.A.F.; Calliari, L.J. (2004) - Geomorphologic Evolution of a Sand Spit Located in the Mouth of a Chocked Costal Lagoon. Lagoa dos Patos: Southern Brazil. Journal of Coastal Research (ISSN: 0749-0208), SI39:255-258 [ICS 2004 Proceedings], Itajaí, Santa Catarina, Brazil.

Boak, E.H.; Turner, I.L. (2005) - Shoreline Definition and Detection: A Review, Journal of Coastal Research, 21(4):688-703. DOI: 10.2112/03-0071.1.

Calliari, L.J.; Winterwerp, J.C.; Fernandes, E.; Cuchiara, D.; Vinzon, S.B.; Sperle, M.; Holland, K.T. (2009) - Fine grain sediment transport and deposition in the Patos Lagoon Cassino beach sedimentary system. Continental Shelf Research, 29(3):515-529. DOI: $10.1016 /$ j.csr.2008.09.019

Fernandes, E.H.L.; Dyer, K.R., Möller, O. O. (2005) - Spatial Gradient in the flow of southern Patos Lagoon. Journal of Coastal Research, 21(4):759-769, DOI: 10.2112/006-NIS.1

Fernandes, E.H.L.; Dyer, K.R.; Möller, O.O.; Niencheski, L.F.H. (2002) - The Patos Lagoon hydrodynamics during El Niño event (1998). Continental Shelf Research, 22(11-13):1699-1713. DOI: 10.1016/S0278-4343(02)00033-X 
Fernandes, E.H.L.; Mariño-Tapia, I.; Dyer, K.R.; Moller, O.O. (2004) - The attenuation of tidal and subtidal oscillations in the Patos Lagoon estuary. Ocean Dynamics, 54(3-4):348-359. DOI: 10.1007/s10236-004-0090-y

Fernandes, E.H.L.; Moller, O.O.; Cuchiara, D.; Marques, W.C. (2012) - Avaliação das Condições de Navegabilidade do Canal de Acesso ao Porto de Rio Grande Após as Obras de Modernização. Technical Report, Rio Grande, RS, Brazil. Unpublished.

Hartmann, C., Harkot, P.R.G. (1990) - Influência do canal São Gonçalo no aporte de sedimentos para o estuário da Laguna dos Patos - RS. Revista Brasileira de Geociências (ISSN: 03757536), 20(1-4):329-332, Sociedade Brasileira de Geologia São Paulo, SP, Brazil. Available on-line at http://sbgeo.org.br/pub_sbg/rbg/vol20_down/2001-2-3-4/2001329.pdf

Hervouet, J.M. (2007) - Hydrodynamics of Free Surface Flows: Modelling With the Finite Element Methods. 360p., Wiley, New York, NY, U.S.A. ISBN: 978-0470035580.

Kjerfve, B. (1986) - Comparative Oceanography of Coastal Lagoons. In: Douglas A. Wolfe, Estuarine Variability, pp. 63-81, Ed Estuarine Variability, Academic Press, Inc, New York, NY, USA. ISBN: 978-0127618906. Available on-line at http://geotest.tamu.edu/userfiles/167/61.pdf

Lorenzo, A.A.; Pagés, J.L. (2007) - Erosion and Accretion of Beach and Spit Systems in Northwest Spain: A Response to Human Activity. Journal of Coastal Research, 23(4):834-845. DOI: $10.2112 / 04-0236.1$

Lumborg, U.; Pejrup, M. (2005) - Modelling of cohesive sediment transport in a tidal lagoon - an annual budget, Marine Geology, 218:1-6. DOI: 10.1016/j.margeo.2005.03.015

Malcherek, A., Piechotta, F., Knoch, D. (2005) - Mathematical module Sedimorph - Validation Document - version 1.1. Technical Report. The Federal Waterways Engineering and Research Institute. Karlshure, Hamburg, Ilmenau, Germany. Unpublished.

Marques, W.C.; Monteiro, I.O.; Fernandes, E.H. (2009) - Numerical modeling of Patos Lagoon plume, Brazil. Continental Shelf Research. 29(3):556-571. DOI: 10.1016/j.csr.2008.09.022

Marques, W.C.; Monteiro, I.O.; Fernandes, E.H.; Möller, O.O. (2010) - Straining and advection contributions to the mixing processo of the Patos Lagoon costal plume, Brazil. Journal of Geofhysical Research, 115(C06019):1-23. DOI: 10.1029/2009JC005653.
Martins, L.R.; Villwock, J.A.; Calliari, L.J. (1987) - Ocorrência de lama na praia do Cassino, (RS). Anais Hidrográficos (ISSN 0373-9260), 33:1-22, Ministério da Marinha, Rio de Janeiro, RJ, Brazil.

Miranda, L.B.; Belmiro, M.C.; Kjerfve, B. (2002) - Principios de Oceanografia Física de Estuários. 424p., Ed. USP, São Paulo, SP, Brazil. ISBN: 978-8531406751

Möller, O.O., Castaing, P. (1999) - Hydrographical characteristics of the estuarine area of Patos Lagoon $\left(30^{\circ} \mathrm{S}\right.$, Brazil). In: G. M. E. Perillo, M. C. Piccolo \& M. Pino-Quivira (eds.), Estuaries of South America, pp.83-100, Springer Berlin Heidelberg, Heidelberg, Germany. ISBN: 978-3642601316. DOI: 10.1007/978-3642-60131-6_5

Möller, O.O.; Castaing, P.; Salomon, J.C.; Lazure, P. (2001) - The influence of local and non- local forcing effects on the subtidal circulation of Patos Lagoon. Estuaries, 24(2):297-311, DOI: $10.2307 / 1352953$.

Niencheski, L.F.; Windom, H.L. (1994) - Nutrient flux and budget in Patos Lagoon Estuary. The Sci. Tot. Environ., 149:53-60. DOI: http://dx.doi.org/10.1016/0048-9697(94)90004-3(1965) - Erosion and deposition of cohesive soils. Journal of the Hydraulics Division (ISSN: 0044-796X), 91(1):105-139, American Society Civil Engineers, New York, NY, U.S.A.

Smith, M.J.; Cromley, R.G. (2012) - Measuring historical coastal change using GIS and the change polygon approach. Transactions in GIS, 16(1):3-15. DOI: $10.1111 / \mathrm{j} .1467-$ 9671.2011.01292.x

Toldo Jr., E.E. (1994) - Sedimentação, Predição do Padrão de Ondas, e Dinâmica Sedimentar da Antepraia e Zona de Surfe do Sistema Lagunar, da Lagoa dos Patos, RS. Porto Alegre. 189p., Tese de Doutorado em Geociências, Universidade Federal do Rio Grande do Sul, Porto Alegre, RS, Brazil. Unpublished.

Žaromskis, R., Gulbinskas, S. (2010) - Main patterns of coastal zone development of the Curonian Spit, Lithuania. Baltica (ISSN: 0067-3064), 23(2):149-156. Vilnius, Klaipédia, Lithuania. Available on-line at http://www.geo.lt/geo/uploads/media/149-156.pdf

Zenkovitch, V.P. (1967). Processes of coastal development. 738p. Translated by D. G. Fry and edited by J. A. Steers. Oliver and Boyd, Edinburgh, Scotland, U.K. 